\title{
The DNA of Bacteria of the World Ocean and the Earth in Cosmic Dust at the International Space Station
}

\author{
T. V. Grebennikova, ${ }^{1,2}$ A. V. Syroeshkin, ${ }^{2}$ E. V. Shubralova, ${ }^{3}$ O. V. Eliseeva, ${ }^{1}$ \\ L. V. Kostina, ${ }^{1}$ N. Y. Kulikova, ${ }^{1}$ O. E. Latyshev, ${ }^{1}$ M. A. Morozova, ${ }^{2}$ A. G. Yuzhakov, ${ }^{1}$ \\ I. A. Zlatskiy $\mathbb{1}^{2,4}{ }^{2,4}$ M. A. Chichaeva, ${ }^{2}$ and O. S. Tsygankov ${ }^{5}$ \\ ${ }^{1}$ Federal Research Center of Epidemiology and Microbiology named after Gamalei, Moscow, Russia \\ ${ }^{2}$ Peoples Friendship University of Russia (RUDN University), 6 Miklukho-Maklaya St, Moscow 117198, Russia \\ ${ }^{3}$ Central Research Institute of Machine Building, Korolev, Russia \\ ${ }^{4}$ Dumanskii Institute of Colloid and Water Chemistry, National Academy of Sciences of Ukraine, Kiev, Ukraine \\ ${ }^{5}$ Korolev Rocket and Space Corporation «Energia», Korolev, Russia
}

Correspondence should be addressed to I. A. Zlatskiy; zlatskiy@ukr.net

Received 3 January 2018; Revised 27 February 2018; Accepted 8 March 2018; Published 18 April 2018

Academic Editor: Martina Heer

Copyright ( $) 2018$ T. V. Grebennikova et al. This is an open access article distributed under the Creative Commons Attribution License, which permits unrestricted use, distribution, and reproduction in any medium, provided the original work is properly cited.

\begin{abstract}
Cosmic dust samples from the surface of the illuminator of the International Space Station (ISS) were collected by a crew member during his spacewalk. The sampler with tampon in a vacuum container was delivered to the Earth. Washouts from the tampon's material and the tampon itself were analyzed for the presence of bacterial DNA by the method of nested PCR with primers specific to DNA of the genus Mycobacteria, DNA of the strains of capsular bacteria Bacillus, and DNA encoding 16S ribosomal RNA. The results of amplification followed by sequencing and phylogenetic analysis indicated the presence of the bacteria of the genus Mycobacteria and the extreme bacterium of the genus Delftia in the samples of cosmic dust. It was shown that the DNA sequence of one of the bacteria of the genus Mycobacteria was genetically similar to that previously observed in superficial micro layer at the Barents and Kara seas' coastal zones. The presence of the wild land and marine bacteria DNA on the ISS suggests their possible transfer from the stratosphere into the ionosphere with the ascending branch of the global electric circuit. Alternatively, the wild land and marine bacteria as well as the ISS bacteria may all have an ultimate space origin.
\end{abstract}

\section{Introduction}

The attention of researchers has always been attracted by the question if there are any microorganism's markers in the conditions of outer space. At the beginning of the 20th century Svante Arrhenius formulated the hypothesis of panspermia $[1,2]$, in which he suggested an extraterrestrial source of life. The development of this hypothesis gave rise to an idea of a possible way of transportation of bacteria and spores through interplanetary and interstellar space. Despite the unpopularity of Arrhenius hypothesis, it had and still has significant influence on the development of entire areas in the fields of biological and space research. Hoyle and Wickramasinghe [3-5] have reexamined the Arrhenius hypothesis using new data. A number of researchers have made an effort to investigate panspermia $[6,7]$ and have paid much attention to the exploration of survival mechanisms of living organisms in the interplanetary space [8-10]. Survival of different types of microorganisms to a prolonged exposure in space was confirmed in experiments, which were performed on the American and Japanese segments of ISS. Thus Antarctic rocks colonized by lichens and fungi (Stihosotskus sp. and Acarospora sp.) were placed for 1.5 years on the ISS, simulating conditions on Mars, and then investigated by molecular methods [11]. Scientists tested bacterial endospores in the space experiment "molecular strategies of microbial adaptation to different space's and planetary climate conditions." It was determined that extraterrestrial 
ultraviolet (UV) emission of sun $(\lambda \geq 110 \mathrm{~nm})$ and also Martian UV $(\lambda \geq 200 \mathrm{~nm})$ are the most harmful factors. However, even after such treatment, there remained a small percentage of live spores [12]. Aerobiological studies have also shown the existence of active and dormant forms of bacterial and fungal spores in the stratosphere, for example, Micrococcus luteum, Mycobacterium albus, Circinella muscae, Aspergillus niger, Papulaspora anomala, Penicillium notatum [13, 14]; Bacillus simplex, Staphylococcus pasteuri, Engyodontium album [15]; Deinococcus aetherius [16]; and Bacillus isronensis [17]. Some researchers have also carried out experiments studying the stability of plant seeds in vacuum and in conditions close to those on Mars [18].

From the time of the first orbiting satellites $[9,19]$ to modern projects (20-24) experiments in open space have shown extraordinary, possibly months-long resilience and survival of different taxonomic groups in the damaging radiation of near space. Results of these experiments confirmed the possibility of organisms preserving viability in the open space for a minimum of two years, and this gave rise to an interest in the question of living organisms being transferred from the stratosphere to the near-Earth space [20, 21].

We might conjecture that viable forms or at least intact DNA can be transferred to the ISS orbit with the ascending branch of the global electric circuit (GEC) [22], which is discussed in the works of Williams and Rycroft [23, 24]. A possible mechanism for the transfer of dispersed particles from the stratosphere to the ionosphere has been recently proposed $[25,26]$, but this idea has not been worked out in detail yet. In this paper samples of space dust from the exterior surface of the ISS were subjected to PCR analysis followed by sequencing of the PCR products. The results obtained indicate the possibility of a mass transfer of the sea bacterial plankton (or its fragments) to the ISS orbit. Alternatively, the transfer of biological material from space to ISS and thence to the ground may be supposed.

\section{Materials and Methods}

2.1. Space Dust Sampling. Cosmonaut Misurkin A. A. (a crew member of the expedition 36) during his spacewalk (22.08.2013) collected the samples of space dust using the tampon from the sampler "TEST" (Central Research Institute of Machine Building). He took 2 probes of dust from the surface of the porthole VL2 of the small research module "Poisk" (MIM2): from the porthole's frame (sample number 1) and from the glass and from the border between glass and frame (sample number 2). The porthole VL2 MIM2 is faced forward, along the vector of the ISS velocity.

Prior to being sent to the ISS, the sampler "TEST" was sterilized in autoclave and with $\gamma$-radiation. After the dust was collected from the surface of the ISS, the tampon holder was screwed into the body of the sampler "TEST" in the open space, so that the swab remained in vacuum until sampler opening in the terrestrial laboratory. In an Earth-based laboratory, the tampon was taken out from the sampler in a laminar flow hood with 2 nd degree of biological protection (complete isolation of the working area air).

2.2. Sample Processing in the Laboratory. Sample processing was conducted in a laminar flow hood with 2nd degree of biological protection. To avoid contamination, the manipulations were carried out with gloves and the operator was provided with a mask and disposable clothing. We made a suspension from tampons in sterile distilled water $(50 \mathrm{ml})$. We also obtained washes with sterile distilled water $(50 \mathrm{ml})$ from the inner surface of sampler's slots for tampons. Then the samples were concentrated using special tubes Amicon Ultra-15 (Millipore), and $400 \mu \mathrm{L}$ of every sample was used for total separation of nucleic acids. The accumulating membrane was also crushed and analyzed.

2.3. Nucleic Acids Separation. Probes themselves and also the samples of collecting membrane were suspended in $6 \mathrm{M}$ solution of guanidine thiocyanate and isolated using the inorganic carrier $\mathrm{SiO}_{2}$. Elution was carried out into $0.03 \mathrm{~cm}^{3}$ of deionized water.

2.4. Polymerase Chain Reaction (PCR). PCR to determine the bacterial plankton and the gene coding for $16 \mathrm{~S}$ ribosomal RNA was performed in a volume of $0.025 \mathrm{~cm}^{3}$. PCR reaction mixture $\left(0.02 \mathrm{~cm}^{3}\right)$, containing $67 \mathrm{mM}$ Tris- $\mathrm{HCl} \mathrm{pH} 8.8$ (at $\left.25^{\circ} \mathrm{C}\right), 16.6 \mathrm{mM}\left(\mathrm{NH}_{4}\right)_{2} \mathrm{SO}_{4}, 0.01 \%$ tween-20, $1.5 \mathrm{mM} \mathrm{MgCl}$, $0.2 \mathrm{mM}$ of each dNTPs, $10 \mathrm{pmol}$ of each primer, and 1.25 units of Taq DNA polymerase, was added to $0.005 \mathrm{~cm}^{3}$ of DNA. We used universal primers F27/R1493 for the amplification of the $16 \mathrm{~S}$ ribosomal RNA. We also used two primer pairs MTG1/MTG4 external and MTG1/MTG4 internal to determine the bacterial plankton gene. Specific bacteria encystation gene primers were utilized to detect the Bacillus anthracis DNA. In all cases we used nested PCR with the technique of "Hot Start" and antibodies to Taq DNA polymerase. Temperature conditions of amplification were as follows: $95^{\circ} \mathrm{C}-30$ seconds (for the first and last cycle $1 \mathrm{~min}$ ); $62^{\circ} \mathrm{C}-30$ seconds; $72^{\circ} \mathrm{C}-30$ seconds (for the first and last cycle $1 \mathrm{~min})$. The ratio of amplification-reamplification cycles in nested PCR was $25: 36$.

2.5. PCR Fragment Sequencing. The sequencing was performed with the primers which were used for PCR. We conducted sequencing of fragments on two chains. The PCR products were purified in special gel purification kit (Geneclean) and then sequenced. Determination of the primary sequence was carried out on an automated DNA sequencer (ABI 377, USA). Primary sequence was analyzed using computer programs MacVector/AssemblyLign (Oxford Molecular Group, USA).

2.6. Analysis of the Nucleotide Sequences. The sequences were analyzed using the following programs: BLAST 2.7.0+ (https://blast.ncbi.nlm.nih.gov/Blast.cgi), DNAStar's MegAlign, and methods MacVector/AssemblyLign (Oxford Molecular Group, USA). Phylogenetic dendrogram was constructed using ClustalV and ClustalW methods.

\section{Results}

Previously, researches have already collected cosmic dust on the ISS, trying to find the ionosphere bacteria from the lower atmosphere. For this task, in the experiment «Tanpopo» a 
TABLE 1: Disperse composition of the washouts from the tampon and "TEST" sampler cavity.

\begin{tabular}{lcccc}
\hline \multirow{2}{*}{ Washout } & \multicolumn{4}{c}{ The position of distribution maximum by the number of particles $(\mu \mathrm{m}) /$ fraction $(\%)$} \\
& 1 fraction & 2 fractions & 3 fractions & 4 fractions \\
\hline Tampon no. 1 & $\mathbf{0 . 0 4 / 0 . 1}$ & - & $\mathbf{0 . 6 9 / 9 8}$ & $\mathbf{5 . 3 / 1 . 9}$ \\
Cavity no. 1 & $0.17 / 22$ & $0.33 / 75$ & $\mathbf{0 . 8 4 / 2 0}$ & $4.8 / 3$ \\
\hline Tampon no. 2 & $\mathbf{0 . 1 1 / 3 2}$ & $\mathbf{0 . 4 4 / 3 6}$ & - & $\mathbf{5 . 5 / 1 2}$ \\
Cavity no. 2 & $0.10 / 38$ & $0.26 / 59$ & $5.0 / 3$ \\
\hline
\end{tabular}

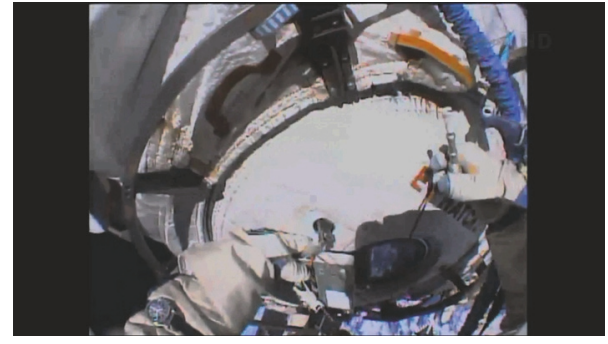

FIGURE 1: The process of sampling with sampler "TEST." Astronaut holds the body of sampler "TEST" in his left hand and the tampon holder screwed out in the open space in the right hand.

special collector of cosmic dust on the basis of hydrophobic aerogel was constructed on the Japanese segment of the ISS [27]. The absence of PCR product in the samples of «Tanpopo» mission can be explained by the short duration of exposure and the location of the sampler. We guessed that a surface of the ISS is a more effective trap for the space dust, because it gathers the dispersed particles from the vacuum, just in the same way as the dust particles, including bacterial and fungal spores, are adsorbed from the gas phase on the surface of aircraft $[28,29]$. Therefore, the most suitable for this purpose was the oncoming flow MIM2, which was docked to the zenith port of the ISS module "Zvezda" eight years ago (10.11.2009). This decision was prompted by the experimental data from Central Research Institute of Machine Building that showed organic contamination on the surface of ISS, which certainly facilitates the adsorption of cosmic dust particles. Figure 1 shows the process of sampling from the exterior of ISS.

It must be emphasized that, to avoid drift of terrestrial bacteria into space, the sampler "TEST" was sterilized in an autoclave and with $\gamma$-radiation. After the dust was collected from the surface of the ISS, the astronaut screwed the tampon holder into the body of the sampler "TEST" in the open space, so that the swab remained in vacuum until the sampler was opened in the terrestrial laboratory, which was also important to avoid nucleic acids contamination. Figure 2 shows the process of the sampler opening in the laboratory of molecular diagnostics.

Then we described the dispersed composition of the samples by the method of dynamic light scattering (DLS) [30]. Table 1 shows the characteristics of the disperse composition of swabs. It should be noted that we visually observed 2 black streaks on the tampon number 2 .

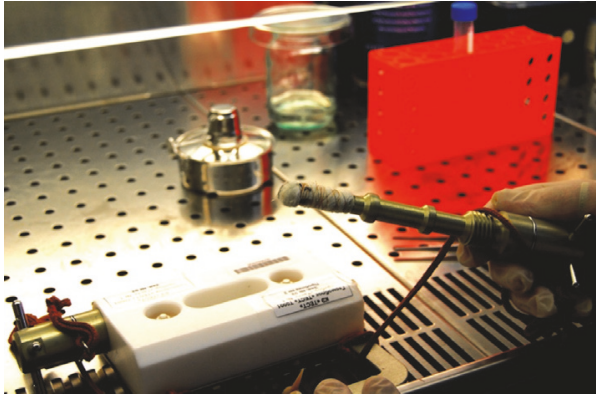

FIGURE 2: The process of the sampler "TEST" opening in the lab in a laminar flow hood with protection degree II. Room where the sample was processed had been pretreated with UV for 24 hours.

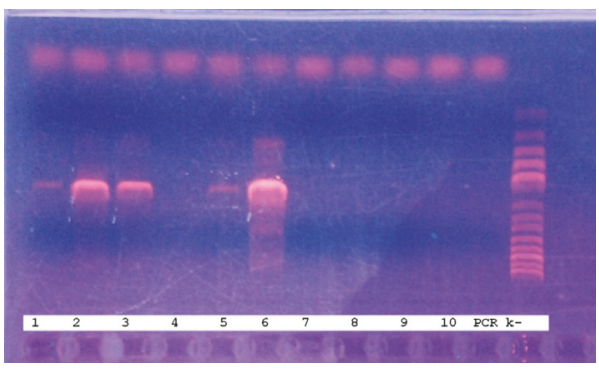

FIGURE 3: The results of amplification of nucleic acids extracted from the samples using universal primers specific for the 16S rRNA gene. Lane 1: tampon number 1, 2: washout from the cavity number 1, 3: membrane of tampon number 2, 4: washout from the tampon number 2, 5: membrane of washout number 2, 6: washout from the cavity number 2, 7: membrane of washout number 1, 8: tampon number 2, 9: tampon number 2, 10: membrane of tampon number 1, 11: negative control (PCR k-). Molecular weight markers (step $100 \mathrm{bp}$.) are applied on the last lane.

DNA encoding 16S ribosomal RNA gene was detected in both samples (washouts from the sampler cavity and the tampon) (Figure 3).

The amplified fragment of unknown DNA of 803 base pairs was sequenced. The nucleotide sequence of this PCR product fragment is shown at Table 2.

Phylogenetic analysis of the nucleotide sequence with the BLAST 2.7.0+ program and NCBI GenBank ${ }^{\circledR}$ DNA sequence databases showed a $100 \%$ identity with the genus Delftia, family Comamonadaceae, order Burkholderiales [31]. The genus taxonomic position is https://www.ncbi.nlm.nih.gov/ Taxonomy $/$ Browser $/$ wwwtax.cgi? mode $=$ Info\&id $=80865 \& l v l=$ $3 \&$ lin $=$ f\&keep $=1 \&$ srchmode $=1 \&$ unlock. 
TABLE 2: Presence of different bacterial DNA in the samples of cosmic dust from the surface of ISS.

\begin{tabular}{|c|c|c|}
\hline Year & Location of dust sampling & Bacteria species/foreign substance \\
\hline \multirow[b]{2}{*}{2013} & Porthole frame of VL2 of the small research module 2 & Delftia sp. \\
\hline & $\begin{array}{l}\text { Glass-frame border of the porthole frame of VL2 of the } \\
\text { small research module } 2\end{array}$ & $\begin{array}{c}\text { Delftia sp., DNA of Mycobacteria sp. (marine } \\
\text { bacterioplankton) }\end{array}$ \\
\hline \multirow{3}{*}{2014} & Cover of the porthole no. 13 of the service module & Organic matter, including peptides and flavonoids \\
\hline & Porthole VL 2 of docking compartment 1 & $\begin{array}{l}\text { DNA of uncultivated soil bacteria from Madagascar } \\
\text { and reservoirs }\end{array}$ \\
\hline & The surface of photoelectron converters of solar panels & DNA of Archaebacteria \\
\hline \multirow{4}{*}{2015} & $\begin{array}{c}\text { Radiator surface of the thermoregulation system of the } \\
\text { service module }\end{array}$ & $\begin{array}{l}\text { DNA sequences close to the genomes of uncultured } \\
\text { fungi }\end{array}$ \\
\hline & $\begin{array}{c}\text { Radiator surface of the thermoregulation system of the } \\
\text { service module, between radiator tubes }\end{array}$ & $\begin{array}{c}\text { DNA of Archaebacteria; DNA of fungi Aureobasidium } \\
\text { sp. }\end{array}$ \\
\hline & Brackets 2434 and 2435 of the service module & DNA sequence close to the plant genomes \\
\hline & Porthole VL 1 of the docking compartment 1 & $\begin{array}{l}\text { DNA of Erythrobasidium sp., Cystobasidium sp., } \\
\text { Staphylococcus saprophyticus, Agrococcus jenensis }\end{array}$ \\
\hline 2016 & $\begin{array}{l}\text { Radiator surface of the thermoregulation system (near } \\
\text { porthole no. 8) of the service module }\end{array}$ & $\begin{array}{l}\text { DNA of Mycobacteria sp. (marine bacterioplankton), } \\
\text { fungi DNA of the genus Bjerkandera }\end{array}$ \\
\hline
\end{tabular}

\begin{abstract}
AGAGTACGGTAGAGGGGGATGGAATTCCGCGTGTAGCAGTGAAATGCGTAGATATGCGGAGGAACACCGATGGCGAAGGCAATCCCCTGGACCTGTACTGACGCTCATGCACGAAAGCGTGGGGAGCAAACAGGATTAGATACCCTGGTAGTCCACGCCCTAAACGATGTCAACTGGTTGTTGGGAATTAGTTTTCTCAGTAACGAAGCTAACGCGTGAAGTTGACCGCCTGGGGAGTACGGCCGCAAGGTTGAAACTCAAAGGAATTGACGGGGACCCGCACAAGCGGTGGATGATGTGGTTTAATTCGATGCAACGCGAAAAACCTTACCCACCTTTGACATGGCAGGAAGTTTCCAGAGATGGATTCGTGCTCGAAAGAGAACCTGCACACAGGTGCTGCATGGCTGTCGTCAGCTCGTGTCGTGAGATGTTGGGTTAAGTCCCGCAACGAGCGCAACCCTTGTCATTAGTTGCTACATTCAGTTGGGCACTCTAATGAGACTGCCGGTGACAAACCGGAGGAAGGTGGGGATGACGTCAAGTCCTCATGGCCCTTATAGGTGGGGCTACACACGTCATACAATGGCTGGTACAGAGGGTTGCCAACCCGCGAGGGGGAGCTAATCCCATAAAACCAGTCGTAGTCCGGATCGCAGTCTGCAACTCGACTGCGTGAAGTCGGAATCGCTAGTAATCGCGGATCAGCATGCCGCGGTGAATACGTTCCCGGGTCTTGTACACACCGCCCGTCACACCATGGGAGCGGGTCTCGCCAGAAGTAGGTAGCCTAACCGCAAGGA
\end{abstract}

Box 1: The sequence of the DNA fragment (size $803 \mathrm{bp}$.) obtained by amplification of samples from ISS surface with universal primers specific to the bacterial $16 \mathrm{~S}$ rRNA gene.

Genus Delftia can be found in a variety of habitats (soils, bottom sediments, active slits, and natural waters), including marine ecosystems (http://www.marinespecies.org/aphia.php? $\mathrm{p}=$ taxdetails\&id=571139).

Apart from the presence of Delftia's DNA, we found in the samples of cosmic dust the DNA of the genus Mycobacteria, some species of which make up to $40 \%$ of the biomass of marine heterotrophic bacterial plankton.

Due to the importance of the results showing the presence of wild bacterial DNA in cosmic dust, we repeated the collection of cosmic dust on the ISS surface many times during several years (2013-2016). Summarized results of bacterial DNA detection in the samples of cosmic dust are shown in Box 1. During the experiments in open space during 2013-2016, more than ten probes of cosmic dust were collected. It is very important that the DNA of the same microorganisms (Delftia sp.; Mycobacteria sp.; Archaebacteria) was repeatedly found at different sites of the station in different years.

At the boundary "glass-frame" we discovered DNA of Mycobacteria sp. also attendant to bacterial plankton. We sequenced the DNA fragment, obtained after PCR with primers specific to gene of Mycobacteria sp. The nucleotide sequence of the PCR fragment is shown at Box 2 .

The resulting nucleotide sequence was compared with the DNA sequences of Mycobacteria sp., obtained earlier from the samples from the coastal and marine surface micro layer in the Russian Western Arctic areas. The results of phylogenetic analysis are presented in Figure 4.

The data presented in Table 2 demonstrates that the DNA of terrestrial microorganisms on the surface of the ISS is not an accidental fact. The presence of the soughtfor DNA in the dust samples points to an undefined process allowing the particles of biological material to be transported to the ionosphere or, alternatively, to the idea that common terrestrial bacteria are constantly being resupplied from space $[4,5]$.

\section{Discussion}

The discovery in the present study of the DNA of the marine and terrestrial bacteria on the surface of the ISS requires 


\section{TAGATCGAGCTGGAGGATCCGTACGAGAAGATCGGCGCTGAGCTGGTCAAGGAAGTTGCCAAGAAGACTGACGACG- TCGCGGGTGACGGCACTACTACCGCCACCGTGCTTGCCCAGGCTCTGGTCAAGGAAGGTCTGCGTAACGTCGTTGC- CGGCGCCAACCCGCTCGGCCTGAAGCGCGGCATCGAGAAGGCCGTGGAGGCCGTCACCAGCTCTCTGCTGGACTCC- GCCAAGGAGATCGACACCAAGGAGCAGATCGCGGCCACCGCGGGCATCTCCGCGGGTGACCAGTCCATCGG}

Box 2: Nucleotide sequence of a PCR fragment obtained by amplification of space dust with universal primers specific to gene of $M y c o b a c t e r i a$ sp.

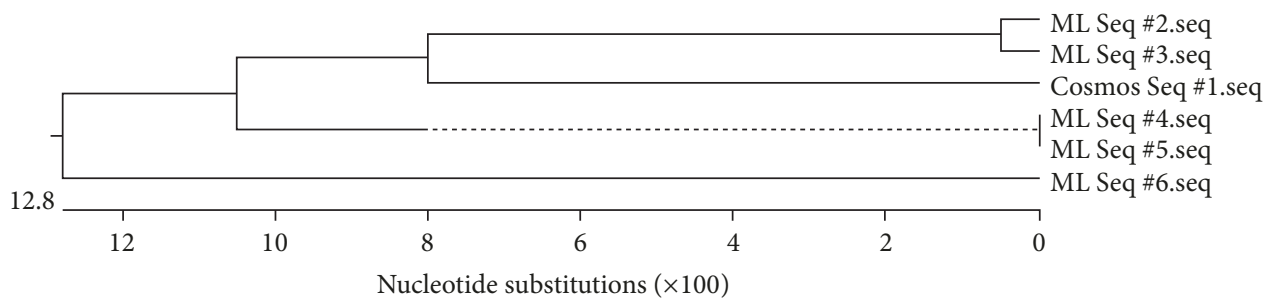

Figure 4: Phylogenetic dendrogram on the basis of the gene fragment obtained with universal primers specific to the Mycobacteria sp. DNA, Cosmos Seq \# 1: the nucleotide sequence of a PCR product from the space dust. ML Seq \# 2-ML Seq \# 6: the nucleotide sequences of PCR products from the samples of sea surface microlayer.

an explanation of the transport mechanisms allowing living matter to reach a height of more than $400 \mathrm{~km}$. The composition of DNA of detected biomaterial excludes single accidental contamination of terrestrial origin. Furthermore, sampling and processing procedures that were used reduced the likelihood of contamination to a minimum. The absence of contamination is supported by clean negative controls, which are very important when using molecular techniques.

Phylogenetic dendrogram (Figure 4) shows that the DNA sequence discovered in samples of cosmic dust has 93\% identity with two of the five Mycobacteria sequences found in the samples from the marine surface micro layer and marine aerosol in the Russian Western Arctic. Of course, this phenomenon needs further exploration, perhaps sequencing of other genes of bacteria from this genus. However, we can state that the upward transport of bacterial DNA is one explanation of the close similarity. Aerosol transport, including living organisms, from the Earth's surface to the troposphere is well described [20, 21, 32-35]. The examples of bacterial genera, which can be attributed to the aerobes of troposphere, indicating the transport mechanisms from the surface of the ocean and land, are presented in the third line of Table 2. Transport from the troposphere to the stratosphere is also well described [36]. It should be stressed that the transfer of dispersed particles from the troposphere to the stratosphere is possible not only during/via catastrophic events (volcanic eruptions, forest fires), but also during the passage of vortex areas where the troposphere dramatically changes its height $[34,35]$. The result of this transfer is a steady presence of a microbial community in the stratosphere (Table 2, line 2), thus raising the question of the upper boundary of the biosphere $[13,20,21]$. Transfer from the stratosphere to the ionosphere might be possible with the ascending branch of the global electrical circuit $[23,24]$ due to a variety of coupled mechanisms of turbulent electrothermodiffusion accompanied by mass transfer of dispersible

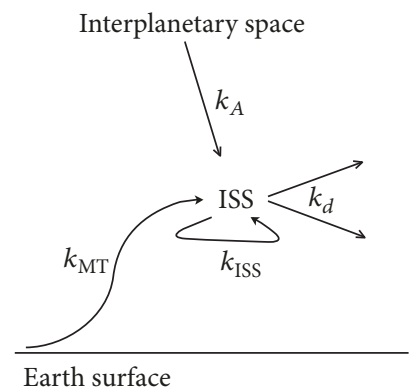

FIgURE 5: Possible ways of intact DNA (bacterial forms) transfer to the orbit of the ISS and from ISS surface. Kinetic constants of different transfer pathways of microorganisms are indicated as follows: $k_{A}$ : hypothetic Arrhenius' way from the interplanetary space, $k_{\mathrm{mt}}$ : possible mass transfer of the dispersed matter from the Earth surface to the ISS orbit with the ascending branch of the global electric circuit, $k_{\text {ISS }}$ : possible contamination way from ISS internal volume to ISS surface, and $k_{d}$ : dissipation of the dust from the ISS surface to space.

material although these processes need further exploration $[25,26]$. It is clear that there are different possible ways of dust transport to (and from) ISS not excluding the possibility of interstellar or interplanetary panspermia [3-5, 37] (Figure 5).

The presence of the DNA of wild terrestrial and marine species of bacteria on the surface of the ISS indicates their possible transfer from the stratosphere to the ionosphere with the ascending branch of the global electric circuit although the details of the process have not been worked out.

The bacteria survival during the transfer from the Earth's surface to the ionosphere is a particular problem. Intact DNA of the genera Delftia and Mycobacteria detected in this paper may indirectly indicate the intactness of the whole cell; otherwise the formation of thymine dimers would make the PCR conducting impossible. However, this issue needs further 
explorations. The question of a living organism's survival in open space has been carefully studied in space experiments [8-10], when the long-term stability of different taxonomic groups to corpuscular radiation, hard X-ray, and ultraviolet radiation was confirmed. In the experiment EXPOSURE-E maximum dose rates reached $0.4 \mathrm{mGy}$ per day [38]. With this dose load and the median lethal dose for bacterial forms from hundreds of Gy [39, 40], the object transported from the Earth's surface into outer space has the potential to remain intact to radiation exposure for hundreds of years. It is worth noting that the intensity of generation of aqueous aerosol, including bacterial plankton $[34,35]$, from the Earth's surface can reach up to $6 \mathrm{Mt}$ per year [41]. However the transport of such material above $30 \mathrm{~km}$ is not well documented. If there can be a migration or diffusion of bacterial particles above $30 \mathrm{~km}$, this supports a hypothesis in which living matter is not required to be brought in with meteoritic or cometary material to the Earth $[8,37]$ but, on the contrary, is dissipated from the Earth biosphere into interplanetary space. The data also supports the possibility of microorganisms coming to the Earth from outside the Earth [3,5].

\section{Conclusion}

We detected the DNA of bacteria of the genus Mycobacteria and extreme bacteria of the genus Delftia (family Comamonadaceae, order Burkholderiales) in the samples of cosmic dust. It was shown that the DNA sequence of one of the bacteria of the genus Mycobacteria was genetically similar to that previously observed in the sea surface microlayer at the Barents and Kara seas' coastal zones. The presence of DNA of wild land and marine bacterial genera on the ISS indicates their possible transfer from the stratosphere into the ionosphere with the ascending branch of the global electric circuit, alternatively to their entry into the Earth's environs from space.

\section{Conflicts of Interest}

The authors declare that there are no conflicts of interest.

\section{Acknowledgments}

The publication was prepared with the support of the "RUDN University Program 5-100.”

\section{References}

[1] S. Arrhenius, "The Propagation of Life in Space," Umschau, vol. 7, pp. 481-485, 1903.

[2] S. Arrhenius, "Worlds in the Making," Harper and Bros, vol. 208, 1907.

[3] F. Hoyle and N. C. Wickramasinghe, "Evolution from Space," London: Dent, vol. 172, 1981.

[4] F. Hoyle and N. C. Wickramasinghe, "Astronomical Origin of life: Steps towards Panspermia," Kluwer, vol. 381, 2000.

[5] C. Wickramasinghe, "The search for our cosmic ancestry," The Search for Our Cosmic Ancestry, pp. 1-196, 2014.

[6] Y. Kawaguchi, Y. Yang, N. Kawashiri et al., "The Possible Interplanetary Transfer of Microbes: Assessing the Viability of
Deinococcus spp. Under the ISS Environmental Conditions for Performing Exposure Experiments of Microbes in the Tanpopo Mission," Origins of Life and Evolution of Biospheres, vol. 43, no. 4-5, pp. 411-428, 2013.

[7] W. L. Nicholson, "Ancient micronauts: interplanetary transport of microbes by cosmic impacts," Trends in Microbiology, vol. 17, no. 6, pp. 243-250, 2009.

[8] G. Horneck, D. M. Klaus, and R. L. Mancinelli, "Space Microbiology," Microbiology and Molecular Biology Reviews, vol. 74, no. 1, pp. 121-156, 2010.

[9] V. M. Baranov, N. D. Novikova, N. A. Polikarpov et al., "The biorisk experiment: 13-month exposure of resting forms of organism on the outer side of the russian segment of the international space station: Preliminary results," Doklady Biological Sciences, vol. 426, no. 1, pp. 267-270, 2009.

[10] J. Hotchin, P. Lorenz, and C. Hemenway, "Survival of microorganisms in space," Nature, vol. 206, no. 4983, pp. 442-445, 1965.

[11] G. Scalzi, L. Selbmann, L. Zucconi et al., "LIFE Experiment: Isolation of Cryptoendolithic Organisms from Antarctic Colonized Sandstone Exposed to Space and Simulated Mars Conditions on the International Space Station," Origins of Life and Evolution of Biospheres, vol. 42, no. 2, pp. 253-262, 2012.

[12] M. Wassmann, R. Moeller, E. Rabbow et al., "Survival of spores of the UV-Resistant bacillus subtilis strain MW01 after exposure to low-earth orbit and simulated martian conditions: Data from the space experiment ADAPT on EXPOSE-E," Astrobiology, vol. 12, no. 5, pp. 498-507, 2012.

[13] A. A. Imshenetsky, S. V. Lysenko, and G. A. Kazakov, "Upper boundary of the biosphere," Applied and Environmental Microbiology, vol. 35, pp. 1-5, 1978.

[14] A. A. Imshenetsky, S. V. Lysenko, G. A. Kazakov, and N. V. Ramkova, "On micro-organisms of the stratosphere," Life Sciences and Space Research, vol. 14, pp. 359-362, 1976.

[15] M. Wainwright, N. C. Wickramasinghe, J. V. Narlikar, and P. Rajaratnam, "Microorganisms cultured from stratospheric air samples obtained at $41 \mathrm{~km}$," FEMS Microbiology Letters, vol. 218, no. 1, pp. 161-165, 2003.

[16] Y. Yang, T. Itoh, S.-I. Yokobori et al., "Deinococcus aetherius sp. nov., isolated from the stratosphere," International Journal of Systematic and Evolutionary Microbiology, vol. 60, no. 4, pp. 776-779, 2010.

[17] S. Shivaji, S. Ara, S. K. Singh, S. Bandi, A. Singh, and A. K. Pinnaka, "Draft genome sequence of Bacillus isronensis strain B3W22, isolated from the upper atmosphere," Journal of Bacteriology, vol. 194, no. 23, pp. 6624-6625, 2012.

[18] D. Tepfer, A. Zalar, and S. Leach, "Survival of plant seeds, their UV Screens, and nptII DNA for 18 months outside the international space station," Astrobiology, vol. 12, no. 5, pp. 517528, 2012.

[19] J. Hotchin, P. Lorenz, and C. L. Hemenway, "The survival of terrestrial microorganisms in space at orbital altitudes during Gemini satellite experiments," Life sciences and space research, vol. 6, pp. 108-114, 1968.

[20] D. J. Smith, "Microbes in the upper atmosphere and unique opportunities for astrobiology research," Astrobiology, vol. 13, no. 10, pp. 981-990, 2013.

[21] D. J. Smith, H. J. Timonen, D. A. Jaffe et al., "Intercontinental dispersal of bacteria and archaea by transpacific winds," Applied and Environmental Microbiology, vol. 79, no. 4, pp. 1134-1139, 2013. 
[22] A. V. Afanasyev, E. V. Shubralova, and O. S. Tsygankov, "Research of cosmochemistry of interplanetary dust in the light of panspermia hypothesis," Cosmonautics and Rocket Engineering, vol. 84, pp. 21-27, 2015.

[23] E. R. Williams, “The global electrical circuit: A review," Atmospheric Research, vol. 91, no. 2-4, pp. 140-152, 2009.

[24] M. J. Rycroft, S. Israelsson, and C. Price, "The global atmospheric electric circuit, solar activity and climate change," Journal of Atmospheric and Solar-Terrestrial Physics, vol. 62, no. 17-18, pp. 1563-1576, 2000.

[25] S. I. Popel, Y. N. Izvekova, and P. K. Shukla, "Nano- and Microscale particles in vortex motions in earth's atmosphere and ionosphere," in Proceedings of the 2010 ICTP International Advanced Workshop on the Frontiers of Plasma Physics, pp. 189200, Italy, July 2010.

[26] S. Benkadda, D. N. Klochkov, S. I. Popel, and Y. N. Izvekova, "Nonlinear excitation of zonal flows and streamers in plasmas," Physics of Plasmas, vol. 18, no. 5, Article ID 052306, 2011.

[27] M. Tabata, Y. Kawaguchi, S. Yokobori et al., "Tanpopo cosmic dust collector: silica aerogel production and bacterial dna contamination analysis," Biological Sciences in Space, vol. 25, no. 1, pp. 7-12, 2011.

[28] F. K. Pfaender and F. E. Swatek, "Interenvironmental transfer of microorganisms on the exterior surfaces of jet aircraft," Journal of Applied Microbiology, vol. 20, no. 2, pp. 227-232, 1970.

[29] C. Năstoiu, V. Răduică, I. Soitu, and I. Gavrilă, “The aerobic air microflora in airplanes on various international routes," Rev Ig Bacteriol Virusol Parazitol Epidemiol Pneumoftiziol, vol. 34, pp. 241-247, 1989.

[30] P. A. Krasovskii, O. V. Karpov, D. M. Balakhanov et al., "Nanoparticles in natural mineral waters. Measurement procedure and results," Measurement Techniques, vol. 53, no. 8, pp. 852-857, 2010.

[31] A. Wen, M. Fegan, C. Hayward, S. Chakraborty, and L. I. Sly, "Phylogenetic relationships among members of the Comamonadaceae, and description of Delftia acidovorans (den Dooren de Jong 1926 and Tamaoka et al. 1987) gen. nov., comb. nov.", International Journal of Systematic Bacteriology, vol. 49, no. 2, pp. 567-576, 1999.

[32] N. DeLeon-Rodriguez, T. L. Lathem, L. M. Rodriguez-R et al., "Microbiome of the upper troposphere: species composition and prevalence, effects of tropical storms, and atmospheric implications," Proceedings of the National Acadamy of Sciences of the United States of America, vol. 110, no. 7, pp. 2575-2580, 2013.

[33] C. A. Kellogg and D. W. Griffin, "Aerobiology and the global transport of desert dust," Trends in Ecology \& Evolution, vol. 21, no. 11, pp. 638-644, 2006.

[34] V. V. Goncharuk, V. B. Lapshin, M. A. Chichaeva et al., “The system of the efficient monitoring of air quality in maritime cities and health resort areas: Pollution of the nearwater layer of the atmosphere with sea aerosols," Journal of Water Chemistry and Technology, vol. 34, no. 2, pp. 79-87, 2012.

[35] V. V. Goncharuk, A. V. Syroeshkin, V. F. Kovalenko, and I. A. Zlatskiy, "Formation of a test system and the choice of test criteria when biotesting natural waters," Journal of Water Chemistry and Technology, vol. 38, no. 6, pp. 349-352, 2016.

[36] J. R. Holton, P. H. Haynes, M. E. McIntyre, A. R. Douglass, R. B. Rood, and L. Pfister, "Stratosphere-troposphere exchange," Reviews of Geophysics, vol. 33, no. 4, pp. 403-439, 1995.

[37] C. Ponnamperuma, Comets and the Origin of Life, vol. 281, Reidel Publ., 1981.
[38] T. Berger, M. Hajek, P. Bilski, C. Körner, F. Vanhavere, and G. Reitz, "Cosmic radiation exposure of biological test systems during the EXPOSE-E mission," Astrobiology, vol. 12, no. 5, pp. 387-392, 2012.

[39] C. Emborg, "Inactivation of dried bacteria and bacterial spores by means of gamma irradiation at high temperatures," Applied and Environmental Microbiology, vol. 27, pp. 830-833, 1974.

[40] P. Setlow, "Spores of Bacillus subtilis: Their resistance to and killing by radiation, heat and chemicals," Journal of Applied Microbiology, vol. 101, no. 3, pp. 514-525, 2006.

[41] K. Y. Kondratyev, "Aerosols and climate: some results and perspectives of remote sensing. 2. Tropospheric aerosols," Ecological Chemistry, vol. 7, pp. 145-163, 1998. 

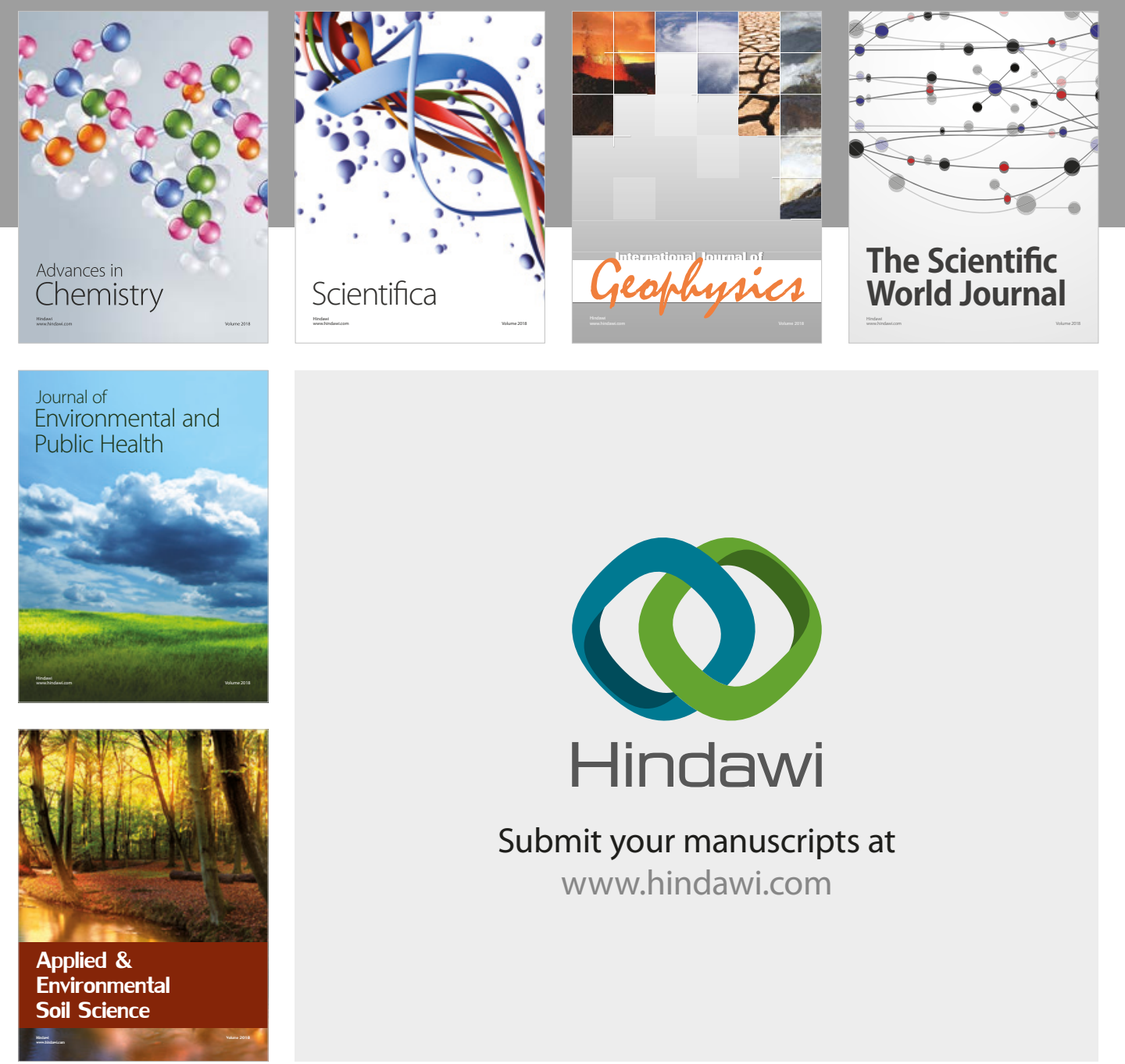

The Scientific

\section{World Journal}
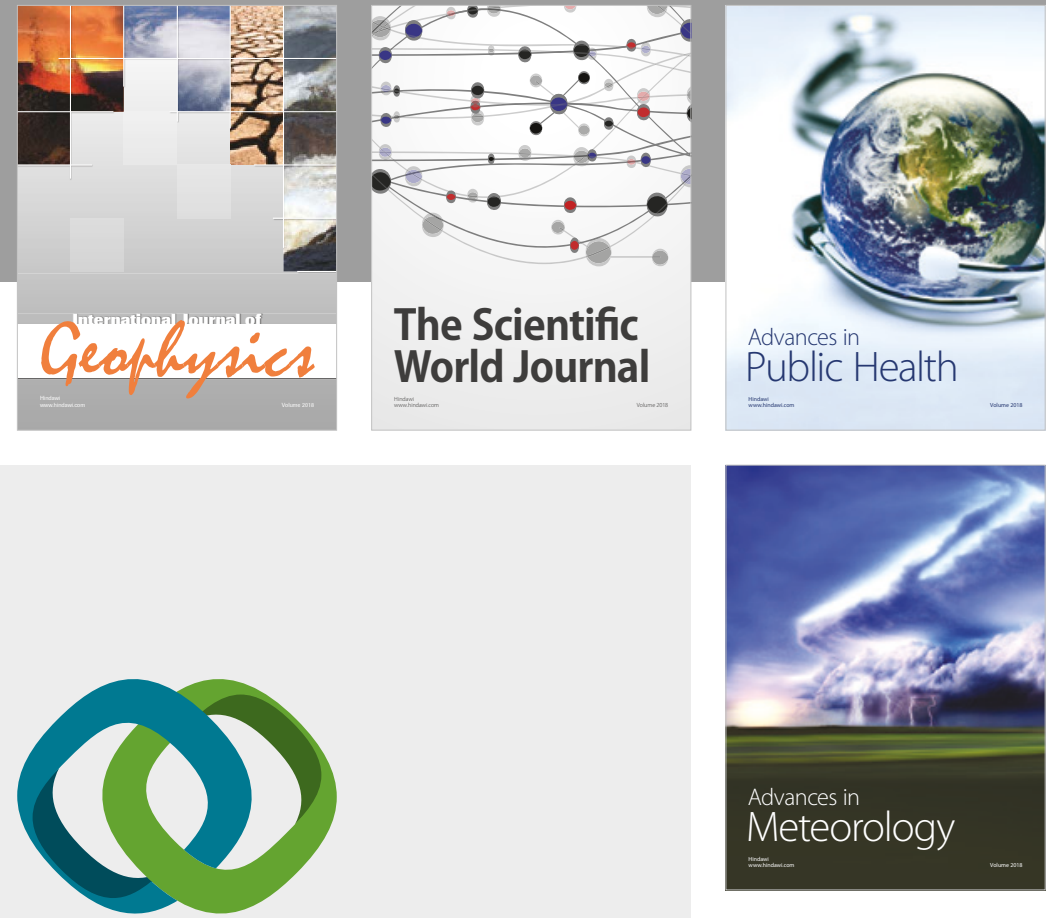

Advan

Public Health

\section{Hindawi}

Submit your manuscripts at

www.hindawi.com
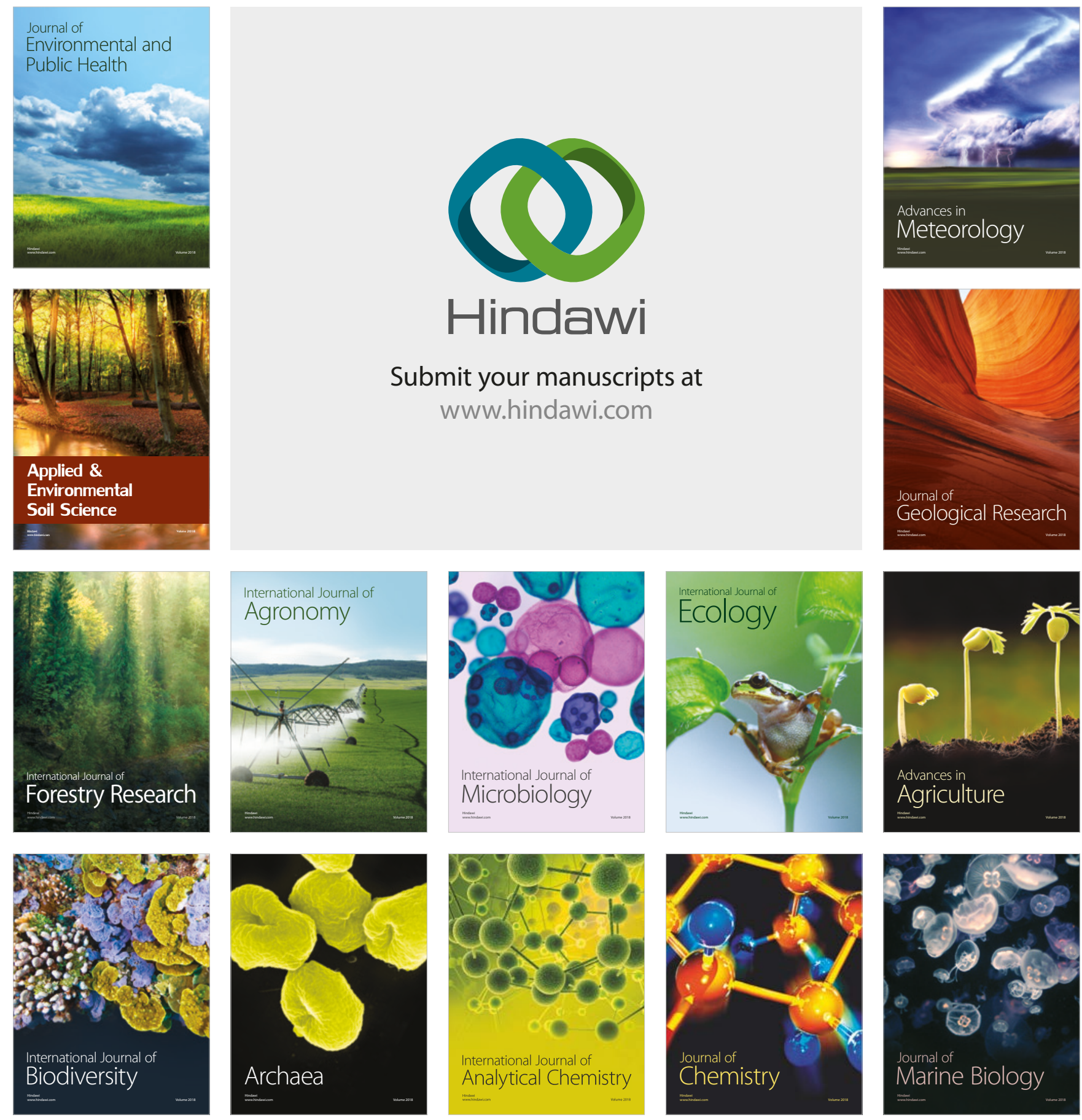